\title{
Neutrophil-to-lymphocyte ratio may guide the choice of treatment in metastatic cancer patients: Chemotherapy or best supportive care
}

\author{
Metastatik kanser hastalarında tedavi seciminde nötrofil-lenfosit oranı yol gösterici \\ olabilir: Kemoterapi veya en iyi destekleyici bakım
}

\section{Serdar Arıcı ${ }^{1}$, Ruhper Çekin ${ }^{1}$}

\begin{abstract}
Aim: We set out in this study to investigate whether the neutrophil-to-lymphocyte ratio is a predictor in deciding whether to either continue palliative chemotherapy or choose the best supportive care for advanced cancer patients.

Methods: Those with advanced solid tumors who had died after palliative chemotherapy were included the study. The patients were divided into two groups based on the time between the beginning of their last chemotherapy regimen and death, at $\leq 60$ or $>60$ days. Neutrophil-to-lymphocyte ratio was calculated using the laboratory values taken before the beginning of the last chemotherapy line. The determinant factors of $\leq 60$-days survival were examined by logistic regression analysis, and a statistical significance level of alpha was accepted as $\mathrm{p}<0.05$.

Results: The study included 404 patients, with the mean age at diagnosis of $61.7 \pm 12.0$ years. The mean neutrophil-to-lymphocyte ratio was calculated as $11.3 \pm 27.1$. In the univariate analysis for determining $\leq 60$-days survival, breast and colorectal cancers, ECOG status, single agent chemotherapy usage, neutrophil count, lymphocyte count and neutrophil-to-lymphocyte ratio were all found to be significant factors. The cutoff value determining the $\leq 60$-days DCD, was determined as NLR $\geq 3.59$. In logistic regression analysis, NLR $\geq 3.59$, as well as ECOG status, were found to be significant factors.

Conclusion: The neutrophil-lymphocyte ratio, combined with ECOG, can predict survival in patients with solid advanced tumors and can therefore help clinicians in choosing to either administer chemotherapy to their patients or direct them to the best supportive care.
\end{abstract}

Keywords: neutrophil-to-lymphocyte ratio, solid tumors, palliative chemotherapy, best supportive care

Öz

Amaç: Bu çalışmada nötrofil-lenfosit oranının (NLO), metastaik kanser hastaları için palyatif kemoterapiye devam etme veya en iyi destekleyici bakımı (BSC) seçme konusunda bir belirleyici olup olmadığını araştırmayı amaçladık.

Yöntemler: Palyatif kemoterapi sonrası ölen metastatik kanser tanılı hastalar çalışmaya dahil edildi. Hastalar son kemoterapi rejimlerinin başlangıcı ile ölüm (DCD) arasındaki süreye göre $\leq 60$ veya $>60$ güne göre iki gruba ayrıldı. Nötrofil-lenfosit oranı, son kemoterapi hattı başlangıcından öncesindeki laboratuvar değerleri kullanılarak hesaplandı. $\leq 60$ günlük DCD'nin belirleyici faktörleri lojistik regresyon analizi ile incelendi ve istatistiksel anlamlılık düzeyi alfa $\mathrm{p}<0,05$ olarak kabul edildi.

Bulgular: Çalışmaya ortalama tanı yaşı $61,7 \pm 12,0$ yıl olan 404 hasta dahil edildi. Ortalama NLO $11,3 \pm 27,1$ olarak hesaplandı. $\leq 60$ günlük DCD belirlenmesi için tek değişkenli analizde, meme ve kolorektal kanser tanıları, ECOG durumu, tek ajan kemoterapi kullanımı, nötrofil sayısı, lenfosit sayısı ve NLO önemli faktörler olarak bulundu. $\leq 60$ günlük DCD'yi belirleyen kesim değeri NLO $\geq 3,59$ olarak belirlendi. Lojistik regresyon analizinde, NLR $\geq 3,59$ ve ECOG durumu önemli faktörler olarak bulundu.

Sonuç: ECOG performans durumu ile kombine edilmiş nötrofil-lenfosit oranı, metastatik kanser hastalarında sağkalımı tahmin edebilir ve bu nedenle klinisyenlerin hastalarına kemoterapi vermeyi veya onları en iyi destekleyici bakıma yönlendirmeyi seçmelerine yardımcı olabilir.

Anahtar Kelimeler: Nötrofil-lenfosit oranı, solid tümörler, palyatif kemoterapi, en iyi destekleyici bakımı
${ }^{1}$ University of Health Sciences, Prof. Dr. Cemil Taşcioğlu City Hospital, Department of Medical Oncology, Istanbul, Turkey

\section{iD}

SA: 0000-0003-2018-6554

RC: 0000-0002-7111-8482

Ethics Committee Approval: The study was approved by Prof. Dr. Cemil Taşcioğlu City Hospital Ethical Committee (48670771-514.10).

Etik Kurul Onayı: Bu çalışma Prof. Dr. Cemil Taşcioğlu Şehir Hastanesi etik kurulundan onay almıştır (48670771-514.10).

Conflict of Interest: No conflict of interest was declared by the authors.

Çıkar Çatışması: Yazar çıkar çatışması bildirmemiştir.

Financial Disclosure: The authors declared that this study has received no financial support.

Finansal Destek: Yazarlar bu çalışma için finansal destek almadıklarını beyan etmişlerdir.

Geliş Tarihi / Received: 01.10.2020

Kabul Tarihi / Accepted: 01.11.2020

Yayın Tarihi / Published: 15.12.2020

Sorumlu yazar / Corresponding author:

Serdar Arıcı

Adres/Address: Department of Medical Oncology, University of Health Sciences, Okmeydani Training and Research Hospital, 34384, Istanbul, Turkey

e-posta: serdararici@hotmail.com Tel/Phone: +90 5447663930

Copyright (C) ACEM 


\section{Introduction}

The short- and long-term prognoses of cancer depend on patient and tumor features such as age, performance status, tumor site, grade, stage and treatment modality [1]. The tumor microenvironment and, in particular, the inflammatory response are thought to play important roles in cancer development and progression, and may be associated with systemic inflammation [2]. The neutrophil-to-lymphocyte ratio (NLR) is a novel marker of inflammation and is measured through routine blood count tests. It becomes elevated in metabolic and inflammatory conditions that are associated with chronic low-grade inflammation. These conditions include diabetes mellitus, thyroiditis, obesity and ulcerative colitis. NLR is even correlated with $\mathrm{HbA1c}$ levels in diabetic patients. Moreover, it helps in differentiating malignant nodules from benign ones in thyroid glands [3-8]. NLR has also been linked to a variety of malignancies such as lung, esophageal, colorectal, ovarian, and head and neck cancers [9-13].

For medical oncologists, determining a prognosis and life expectancy is critical to choosing either best supportive care (BSC) or chemotherapy. Survival estimates that clinicians make, usually guided only by their intuition and clinical experience, are often incorrect, and clinicians tend to believe that their patients have longer to live than they actually do [14]. This error sometimes results in treatment that is too aggressive [15, 16]. Although physicians appear to be wrong less often when assessing short- ( $<15$ days) and long-term ( $>6$ months) survival, there is a substantial period of uncertainty - a better prognostic assessment could help improve patient care [15]. While prognostic factors and predictive tools have been explored and developed to improve a clinician's ability to estimate life expectancy, they often require complex parameters, such as the inclusion of patient and tumor features [17, 18].

We investigated the NLR's ability to act as a predictor in deciding whether to continue palliative chemotherapy or to instead employ BSC in advanced cancer patients.

\section{Material and methods}

This trial was planned as a retrospective single-center study. Medical details were obtained from the archive files of patients with advanced solid tumors, who had died between January 2018 and December 2019 after palliative chemotherapy treatment in the medical oncology clinic of Prof. Dr. Cemil Taşçıŏlu City Hospital. These were patients who had been admitted to the oncology clinic and would routinely, after a 12 hour fast, have blood samples taken. The blood was drawn from the antecubital vein and a blood analysis was performed. Tubes containing ethylenediaminetetraacetate (for complete blood counts) and anticoagulant-free gel tubes (for biochemical parameters) were used to store the blood samples. The complete blood count parameters were tested in a hemogram autoanalyzer (Mindray, China), and the biochemical parameters were examined in an autoanalyzer (Beckman Coulter, USA), using a colorimetric method. Disease staging was performed according to the Tumor, Node, Metastasis (TNM) staging system. Patients with missing data were not included in the study. Patients with infectious diseases, other inflammatory diseases such as rheumatoid arthritis and ulcerative colitis, hematologic malignancies, and patients who had received granulocyte colonystimulating factor $\leq 4$ weeks before last chemotherapy line were excluded from the study. The patients were divided into two groups, according to DCD, as $\leq 60$ or $>60$ days [15].

The demographic features included age at diagnosis and death, histologic type, Eastern Cooperative Oncology Group
(ECOG), status both at diagnosis and before beginning the last chemotherapy regimen, as well as stage, the number of total treatment lines, the last chemotherapy modality (single agent or combination) and the time between the beginning of their last chemotherapy regimen and death (DCD). Also noted were the laboratory values before the beginning of the last chemotherapy line, such as white blood cell count (WBC), red blood cell count (RBC), hemoglobin ( $\mathrm{Hb})$, hematocrit (HCT), mean platelet volume (MPV), total platelet count (TPC), total neutrophil count (TNC), total lymphocyte count (TLC), total monocyte count (TMC), creatinine, alanine aminotransferase (ALT), aspartate aminotransferase (AST) and lactate dehydrogenase (LDH), and $C$ reactive protein (CRP). The NLR was calculated by dividing the TNC count by TLC. Biochemical parameters were presented as either below or above the reference range, based on the reference intervals used in the laboratory.

\section{Statistical Analysis}

SPSS 15.0 for Windows was used for statistical analysis. Descriptive statistics were given as a number and as a percentage for categorical variables, average and standard deviation, and as a minimum and maximum for numeric variables. Comparisons of the numerical variables in two independent groups were made using the Mann Whitney U test, since the normal distribution condition was not met. Comparisons of the ratios in the groups were made using the Chi-Square test. The determinant factors which $p$ value $<0.250$ in univariate analysis, were examined by logistic regression analysis, the cutoff value was calculated by ROC curve analysis and a statistical significance level of alpha was accepted as $\mathrm{p}<$ 0.05 .

\section{Results}

The study included 404 patients $(68.8 \%$ men and $31.2 \%$ women) with solid tumors who had died after palliative chemotherapy. The mean age at diagnosis was $61.7 \pm 12.0$ (22$89)$ years. The five most common cancer types were non-smallcell lung (33.4\%), gastric (15.3\%), small-cell lung (9.9\%), colorectal $(8.7 \%)$ and breast cancers $(6.9 \%)$. The patient numbers for local, locally advanced and metastatic stage at the diagnosis were $22(5.4 \%), 97(24.0 \%)$ and 285 (70.5\%), respectively. The mean number of chemotherapy lines was 1.40 (min-max 1-8). The number of patients that received single, doublet and triplet chemotherapy as a last chemotherapy regimen was $133(32.9 \%), 228(56.4 \%)$ and 43 (10.6\%), respectively. The number of patients with an ECOG status of 0, 1, 2 and 3 before beginning the last chemotherapy regimen was 10 (2.5\%), 40 $(9.9 \%), 316(78.2 \%)$ and $38(9.4 \%)$, respectively. The mean DCD was $60.6 \pm 99.9$ days (0-962). The number of patients in the two groups according to the DCD, whether $\leq 60$ or $>60$ days, was $291(72.0 \%)$ and $113(28.0 \%)$, respectively (Table 1).

The mean TNC and TLC counts were $7.32 \pm 5.52 * 103 \mathrm{uL}$ and $1.29 \pm 0.87 * 103 \mathrm{uL}$, respectively. The mean NLR was calculated as $11.3 \% \pm 27.1 \%$. Other laboratory parameters are laid out in Table 2 .

In the univariate analysis, breast and colorectal cancers were higher in patients who lived $\leq 60$ days after the last chemotherapy than in those who lived $>60$ days $(\mathrm{p}=0.035$ and $\mathrm{p}=0.040$, respectively). Also, single-agent chemotherapy usage was higher in the $\leq 60$ days-group. There was a significant difference between the groups with respect to ECOG status. The number of ECOG 0/1 patients was higher in > 60-days group, and the ECOG $2 / 3$ patient number was higher in the $\leq 60$-day group $(\mathrm{p}=0.002)$ (Table 1$)$. The mean $\mathrm{TNC}$ was higher $(7.75 \pm 5.76103 \mathrm{uL}$ and $6.21 \pm 4.69103 \mathrm{uL}$, respectively, where $\mathrm{p}=$ $0.014)$ and the TLC was lower $(1,22 \pm 0.87103 \mathrm{uL}$ and $1,48 \pm 0.83$ $103 \mathrm{uL}$, respectively, where $\mathrm{p}=0.003)$ in the $\leq 60$-days group 
than in > 60-days group.

Table 1. Demographic and pathologic features of patients and univariate analysis for determining the $60 \leq$ days survival.

\begin{tabular}{|c|c|c|c|c|c|c|c|c|}
\hline \multicolumn{2}{|l|}{ Variables } & \multicolumn{2}{|c|}{$\begin{array}{l}\text { All patients } \\
\quad(n=404)\end{array}$} & \multicolumn{2}{|c|}{$\begin{array}{l}60 \leq \text { days } \\
(n=291)\end{array}$} & \multicolumn{2}{|c|}{$\begin{array}{l}>60 \text { days } \\
(n=113)\end{array}$} & \multirow[t]{2}{*}{$\mathrm{p}$} \\
\hline & & $\mathrm{n}$ & $\%$ & $\mathrm{n}$ & $\%$ & $n$ & $\%$ & \\
\hline \multirow{2}{*}{ Gender } & Male & 278 & 68.8 & 202 & 69.4 & 76 & 67.3 & \multirow{2}{*}{0.674} \\
\hline & Female & 126 & 31.2 & 89 & 30.6 & 37 & 32.7 & \\
\hline \multirow[t]{6}{*}{$\begin{array}{l}\text { Age at } \\
\text { diagnosis(year) }\end{array}$} & Mean+SD & \multicolumn{2}{|c|}{$\begin{array}{c}61.7 \pm 12.0 \\
(22-89)\end{array}$} & \multicolumn{2}{|c|}{$62.0 \pm 12.2$} & \multicolumn{2}{|c|}{$60.8 \pm 11.8$} & 0.350 \\
\hline & NSCLC & 135 & 33.4 & 98 & 33.7 & 37 & 32.7 & 0.858 \\
\hline & SCLC & 40 & 9.9 & 33 & 11.3 & 7 & 6.2 & 0.120 \\
\hline & Breast & 28 & 6.9 & 25 & 8.6 & 3 & 2.7 & 0.035 \\
\hline & Colorectal & 35 & 8.7 & 20 & 6.9 & 15 & 13.3 & 0.040 \\
\hline & Prostate & 7 & 1.7 & 4 & 1.4 & 3 & 2.7 & 0.405 \\
\hline \multirow[t]{6}{*}{ Diagnosis } & Gastric & 62 & 15.3 & 41 & 14.1 & 21 & 18.6 & 0.261 \\
\hline & $\mathrm{RCC}$ & 1 & 0.2 & 1 & 0.3 & 0 & 0.0 & 1.000 \\
\hline & Sarcoma & 8 & 2.0 & 6 & 2.1 & 2 & 1.8 & 1.000 \\
\hline & Pancreas & 20 & 5.0 & 16 & 5.5 & 4 & 3.5 & 0.415 \\
\hline & Bladder & 11 & 2.7 & 5 & 1.7 & 6 & 5.3 & 0.081 \\
\hline & Other & 57 & 14.1 & 42 & 14.4 & 15 & 13.3 & 0.764 \\
\hline \multirow{3}{*}{$\begin{array}{l}\text { Last Ctx } \\
\text { regimen }\end{array}$} & Single & 133 & 32.9 & 109 & 37.4 & 26 & 23.0 & \multirow{3}{*}{0.024} \\
\hline & Doublet & 228 & 56.4 & 157 & 54.0 & 72 & 63.7 & \\
\hline & Triplet & 43 & 10.6 & 25 & 8.6 & 15 & 13.3 & \\
\hline $\begin{array}{l}\text { Chemotherapy } \\
\text { line number }\end{array}$ & $\begin{array}{l}\text { Med (min- } \\
\max )\end{array}$ & \multicolumn{2}{|c|}{$2(1-8)$} & \multicolumn{2}{|c|}{$2(1-8)$} & \multicolumn{2}{|c|}{$1(1-7)$} & 0.684 \\
\hline \multirow{4}{*}{$\begin{array}{l}\text { ECOG before } \\
\text { last Ctx } \\
\text { regimen }\end{array}$} & 0 & 10 & 2.4 & 6 & 2.1 & 4 & 3.6 & \multirow{4}{*}{0.002} \\
\hline & 1 & 40 & 10.0 & 19 & 6.6 & 21 & 18.8 & \\
\hline & 2 & 316 & 78.2 & 235 & 81.0 & 79 & 70.5 & \\
\hline & 3 & 38 & 9.4 & 30 & 10.3 & 8 & 7.1 & \\
\hline DCD (days) & Mean+SD & $\begin{array}{c}60.6 \pm \\
99.9 \\
\end{array}$ & & & & & & \\
\hline
\end{tabular}

ECOG: Eastern Cooperative Oncology Group scales, Ctx: chemotherapy,

NSCLC: non-smallcelllungcancer, SCLC: small cell lungcancer, RCC: renal cell carcinoma, DCD: duration between last chemotherapy regimen and death, min:

minimum, max: maximum, SD: standard deviation

The mean NLR values were $13.5 \pm 31.4 \%$ and $5.8 \pm 6.5 \%$, respectively, in $\leq 60$ days group and in $>60$-days group ( $\mathrm{p}<$ 0.001). Also, AST (51.1 \pm 85.8 and 39,2 \pm 89.6 , respectively, where $\mathrm{p}=0.004)$ and ALT values (36.7 \pm 45.2 and 27.0 \pm 63.2 , respectively, where $\mathrm{p}<0.001)$ were higher in the $\leq 60$-days group than in $>60$-days group. There was no difference in terms of CRP and LDH between the groups. (Table 2)

Table 2. Laboratory features of patients and univariate analysis for determining the $60 \leq$ days duration between last chemotherapy regimen and death

\begin{tabular}{|c|c|c|c|c|}
\hline Variables & $\begin{array}{l}\text { Allpatients } \\
(\mathrm{n}=404) \\
\text { mean } \pm \text { SD }\end{array}$ & $\begin{array}{c}60 \leq \text { days } \\
(n=291) \\
\text { mean } \pm \text { SD }\end{array}$ & $\begin{array}{c}>60 \text { days } \\
(n=113) \\
\text { mean } \pm S D\end{array}$ & $\mathrm{p}$ \\
\hline $\begin{array}{l}\text { WBC } \\
\left(10^{\wedge} 3 / \mathrm{uL}\right)\end{array}$ & $9.36 \pm 5.99$ & $9.69 \pm 6.22$ & $8.52 \pm 5.30$ & 0.146 \\
\hline $\operatorname{Neu}\left(10^{\wedge} 3 / \mathrm{uL}\right)$ & $7.32 \pm 5.52$ & $7.75 \pm 5.76$ & $6.21 \pm 4.69$ & 0.014 \\
\hline $\begin{array}{l}\text { Lym } \\
\left(10^{\wedge} 3 / \mathrm{uL}\right)\end{array}$ & $1.29 \pm 0.87$ & $1.22 \pm 0.87$ & $1.48 \pm 0.83$ & 0.003 \\
\hline NLR \% & $11.3 \pm 27.1$ & $13.5 \pm 31.4$ & $5.8 \pm 6.5$ & $<0.001$ \\
\hline $\operatorname{Eos}\left(10^{\wedge} 3 / \mathrm{uL}\right)$ & $0.11 \pm 0.27$ & $0.10 \pm 0.3$ & $0.14 \pm 0.24$ & 0.019 \\
\hline $\mathrm{Hgb}(\mathrm{g} / \mathrm{dL})$ & $10.8 \pm 1.7$ & $10.9 \pm 1.7$ & $10.6 \pm 1.6$ & 0.212 \\
\hline Plt $\left(10^{\wedge} 3 / \mathrm{uL}\right)$ & $271.4 \pm 161.3$ & $265.4 \pm 158.1$ & $286.8 \pm 169.0$ & 0.292 \\
\hline PDW (fL) & $14.3 \pm 8.1$ & $14.2 \pm 2.5$ & $14.6 \pm 14.8$ & 0.004 \\
\hline Crea (mg/dL) & $\begin{array}{l}0.87 \pm 0.58 \\
\text { Median } \\
(\text { min-max) }\end{array}$ & $\begin{array}{c}0.85 \pm 0.57 \\
\text { Median (min- } \\
\text { max) }\end{array}$ & $\begin{array}{c}0.90 \pm 0.60 \\
\text { Median (min- } \\
\text { max) }\end{array}$ & 0.205 \\
\hline AST (U/L) & $24(6-920)$ & $26(6-920)$ & $20(7-917)$ & 0.004 \\
\hline ALT (U/L) & $20(3-645)$ & $23(3-411)$ & $17(5-645)$ & $<0.001$ \\
\hline LDH (U/L) & $\begin{array}{c}238(22- \\
4552)\end{array}$ & $237(23-4478)$ & $\begin{array}{c}239(22- \\
4552)\end{array}$ & 0.987 \\
\hline $\mathrm{CRP}(\mathrm{mg} / \mathrm{dL})$ & $\begin{array}{c}32(0.75- \\
1427)\end{array}$ & $34(0.75-1427)$ & $25(1.92-375)$ & 0.330 \\
\hline
\end{tabular}

WBC: white blood count, Neu: neutrophil, Lym: lymphocyte, NLR: neutrophil to lymphocyte ratio, Eos: eosinophil, Hgb: hemoglobin, Plt: platelet, PDW: platelet distribution width, Crea: creatinine, AST: aspartate aminotransferase, ALT: alanine aminotransferase, LDH: lactate dehydrogenase, SD: Standard deviation
The receiver operating characteristic (ROC) curve was drawn using the NLR ratios at the time before the beginning of the last chemotherapy line; the corresponding area under the curve value was found to be $0.636(95 \% \mathrm{Cl} 0.577-0.694, \mathrm{p}<$ $0.001)$. The cutoff value determining the $\leq 60$-day DCD was determined as NLR $\geq 3.59 \%$, with $70.0 \%$ sensitivity and $51.0 \%$ specificity (Fig. 1). The median DCD was lower in patients with NLR $\geq 3.59 \%$ than $<3.59 \%$ (26 days and 42 days, respectively, where $\mathrm{p}=0.001)$ (Table 3).

Table 3. Survivals differences between groups according to NLR cut-off value.

\begin{tabular}{|c|c|c|c|c|c|}
\hline & & & & & \\
\hline & & & & & \\
\hline & Mean \pm SD & $\begin{array}{l}\text { Min-Max } \\
\text { (Median) }\end{array}$ & Mean \pm SD & $\begin{array}{l}\text { Min-Max } \\
\text { (Median) }\end{array}$ & $\mathrm{p}$ \\
\hline $\begin{array}{l}\text { DDD } \\
\text { (month) }\end{array}$ & $13.8 \pm 20.6$ & $0-150(7)$ & $9.4 \pm 14.5$ & $0-148(5)$ & 0.002 \\
\hline $\begin{array}{l}\text { DCD } \\
\text { (day) }\end{array}$ & $86.4 \pm 130.0$ & $2-810(42)$ & $47.0 \pm 76.2$ & $0-962(26)$ & 0.001 \\
\hline
\end{tabular}

In multivariate logistic regression analysis for factors determining the $\leq 60$-day DCD, an NLR $\geq 3.59 \%$, as well as ECOG status, were found to be significant factors $(\mathrm{p}<0.001$, and $\mathrm{p}<0.009$, respectively) (Table 4).

Table 4. Multivariate analysis for determining the $60 \leq$ days duration between last chemotherapy regimen and death.

\begin{tabular}{|c|c|c|c|c|c|}
\hline & & $\mathrm{p}$ & OR & & $\mathrm{CI}$ \\
\hline & & 0.003 & & & \\
\hline ECOGs at & 0 & 0.631 & 0.662 & 0.123 & 3.564 \\
\hline & 1 & 0.009 & 0.225 & 0.074 & 0.685 \\
\hline & 2 & 0.819 & 0.899 & 0.363 & 2.230 \\
\hline & & 0.875 & & & \\
\hline $\begin{array}{l}\text { Stage at } \\
\text { diagnosis }\end{array}$ & 2 & 0.989 & 0.992 & 0.290 & 3.396 \\
\hline & 3 & 0.787 & 1.211 & 0.301 & 4.869 \\
\hline $\begin{array}{l}\text { Chemotherapy } \\
\text { line number }\end{array}$ & & 0.627 & 1.106 & 0.737 & 1.658 \\
\hline WBC & & 0.902 & 1.003 & 0.956 & 1.052 \\
\hline NLR & $\geq 3.59$ & $<0.001$ & 2.696 & 1.553 & 4.679 \\
\hline $\mathrm{Hgb}$ & & 0.419 & 1.068 & 0.911 & 1.252 \\
\hline MPV & & 0.722 & 0.963 & 0.785 & 1.183 \\
\hline Crea & & 0.484 & 0.864 & 0.574 & 1.300 \\
\hline ALT & & 0.167 & 1.004 & 0.998 & 1.009 \\
\hline & SCLC & 0.511 & 1.382 & 0.527 & 3.626 \\
\hline & Breast & 0.058 & 4.693 & 1.086 & 20.287 \\
\hline & Colorectal & 0.251 & 0.616 & 0.270 & 1.409 \\
\hline & Bladder & 0.525 & 0.620 & 0.142 & 2.710 \\
\hline
\end{tabular}

ECOG: Eastern Cooperative Oncology Group scales, WBC: white blood count, NLR: neutrophil to lymphocyte ratio, Hgb: hemoglobin, MPV: mean platelet volume, Crea: creatinine, ALT: alanine aminotransferase, Ctx: chemotherapy, SCLC: small cell lung cancer,

\section{Discussion}

In this study, our aim was to investigate whether NLR is a predictor of survival in cancer patients that received palliative chemotherapy. We found that NLR and ECOG status were independent factors for $\leq 60$ days' survival in patients with advanced solid tumors. 


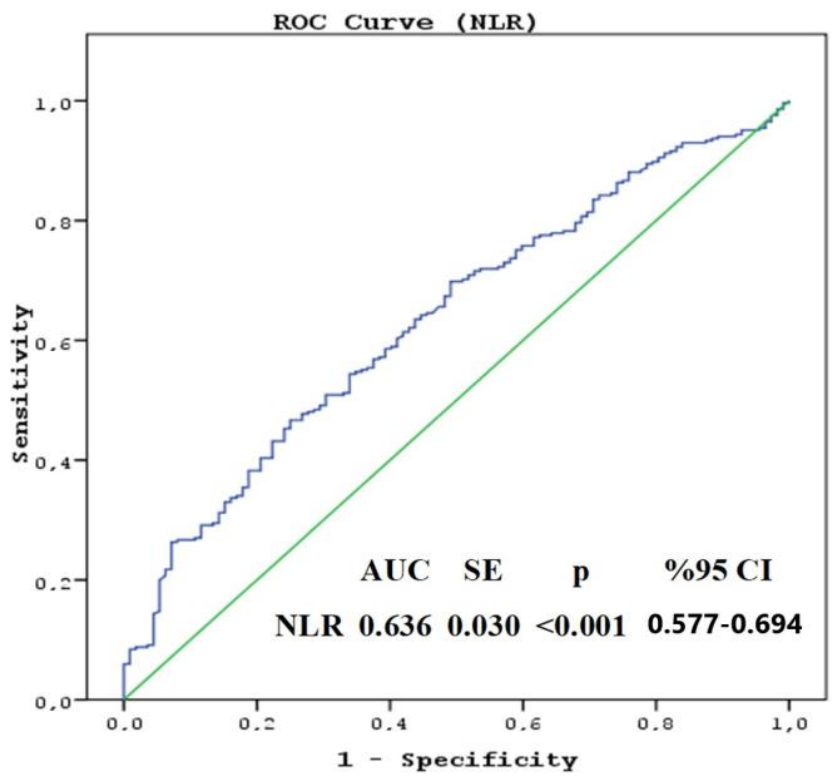

Fig. 1: Receiver operating characteristic curve analyses for $\leq 60$ day survival.

The cutoff value determining the $\leq 60$ day DCD, was determined as NLR $\geq$ $3.59 \%$, with $70.0 \%$ sensitivity and $51.0 \%$ specificity.

NLR is an indicator of inflammation and immune system response, and has been accepted as a prognostic factor in various malignancies. Based on the findings of current studies, it is relatively consistent to conclude that a higher NLR is a negative prognostic factor for many cancer types such as renal cell carcinoma, malignant melanoma, and gastric, pancreatic, breast and colorectal cancers [19-28]. But a few studies have focused on which parameter is a predictor of early death. In a trial published in 2007, with a total of 177 patients with solid tumors, two-month survival predictors were investigated, and the Karnofsky index, the number of metastatic sites, low serum albumin and LDH concentration were found to be independent factors in predicting two months' survival. Also, with univariate analysis, a high WBC was found to be a poor prognostic factor, but this relation was not observed with multivariate analysis. The neutrophil-to-lymphocyte ratio was not evaluated in this study [15].

Earlier studies have focused solely on performance status in terms of survival estimation. For example, one study set out to improve the ability to estimate the survival of terminally ill cancer patients and found that the factor most strongly associated with shorter survival was poor performance status [1]. However, these patients' NLR was not included in the analysis. Also, a palliative performance scale (consisting of the subheadings of mobility, activity/disease finding, self-care, nutrition and level of consciousness) was evaluated for estimating survival. The study's findings revealed that the palliative performance scale upon admission, along with gender and age, was a strong predictor of survival in patients already identified as palliative. However, survival had not been a significant part of the diagnoses [29]. A trial published in 2008 set out to derive and validate a simple predictive model for the survival of patients who had metastatic cancer and attended a palliative radiotherapy clinic. This model, different from older models (including six separate factors) needed three prognostic factors: primary cancer site, site of metastases and KPS. The study did not find a difference between the two models in terms of estimating survival [30]. In another study, which included a total of 299 patients, the prognostic value was based on a combination of performance status (PS) factors, with either the LDH level or the lymphocyte count being evaluated. This study found that a PS $>1$, a lymphocyte count $\leq 700 / \mu \mathrm{L}$ and $\mathrm{LDH}>$ $600 \mathrm{UI} / \mathrm{L}$ were independent predictors of short-term survival, as well as the interleukin 6 (IL-6) level, the serum albumin concentration and the platelet count [31]. In the studies discussed above, the researchers either focused only on the PS or on models with complex components, but they did not evaluate NLR in terms of survival estimation. We found that easily accessible parameters such as NLR and ECOG status were independent factors for $\leq 2$ months' survival in patients with advanced solid tumors. Also, we found that in the study's population, there was no relation between LDH and $a \leq$ twomonths survival time.

This is a retrospective study with a specific limitation: We could not include albumin values in the analysis since not all patients had the respective data. But this is the first study to focus on the NLR as a predictor in terms of survival estimation in patients with advanced solid tumors, independent of tumor type.

In conclusion, NLR combined with ECOG PS appears to better predict survival in patients with solid advanced tumors and thereby can help clinicians either administer chemotherapy to their patients or direct them to the best supportive care.

\section{References}

1.Allard P, Dionne A, Potvin D. Factors associated with length of survival among 1081 terminally ill cancer patients. J Palliat Care. 1995; 11(3):20-24.

2.Aggarwal BB, Vijayalekshmi RV, Sung B. Targeting inflammatory pathways for prevention and therapy of cancer: short-term friend, longterm foe. Clin Cancer Res. 2009; 15(2):425-430.

3.Duman TT, Aktas G, Atak BM, Kocak MZ, Erkus E, Savli H. Neutrophil to lymphocyte ratio as an indicative of diabetic control level in type 2 diabetes mellitus. Afr Health Sci. 2019; 19(1):1602-1606.

4.Aktas G, Sit M, Dikbas O, Erkol H, Altinordu R, Erkus E, et al. Elevated neutrophil-to-lymphocyte ratio in the diagnosis of Hashimoto's thyroiditis. Rev Assoc Med Bras. 2017; 63(12):10651068 .

5.Fang Q, Tong YW, Wang G, Zhang N, Chen WG, Li YF, et al. Neutrophil-to-lymphocyte ratio, obesity, and breast cancer risk in Chinese population. Medicine 2018; 97(30):e11692.

6.Posul E, Yilmaz B, Aktas G, Kurt M. Does neutrophil-to-lymphocyte ratio predict active ulcerative colitis? Wiener klinische Wochenschrift 2015; 127(7-8):262-265.

7.Bilgin S, Aktas G, Zahid Kocak M, Atak BM, Kurtkulagi O, Duman TT, et al. Association between novel inflammatory markers derived from hemogram indices and metabolic parameters in type 2 diabetic men. Aging Male. 2019 Jun 28:1-5. doi: $10.1080 / 13685538.2019 .1632283$

8.Sit M, Aktas G, Erkol H, Yaman S, Keyif F, Savli H. Neutrophil to Lymphocyte Ratio is Useful in Differentiation of Malign and Benign Thyroid Nodules. Puerto Rico Health Sci J. 2019; 38(1):60-63.

9.Sakin A, Sahin S, Yasar N, Demir C, Arici S, Geredeli C, et al. The Relation between Hemogram Parameters and Survival in ExtensiveStage Small Cell Lung Cancer. Oncol Res Treat. 2019; 42(10):506515.

10. Yodying H, Matsuda A, Miyashita M, Matsumoto S, Sakurazawa N, Yamada M, et al. Prognostic Significance of Neutrophil-toLymphocyte Ratio and Platelet-to-Lymphocyte Ratio in Oncologic Outcomes of Esophageal Cancer: A Systematic Review and Metaanalysis. Ann Surg Oncol. 2016; 23(2):646-654.

11.Pedrazzani C, Mantovani G, Fernandes E, Bagante F, Luca Salvagno G, Surci N, et al. Assessment of neutrophil-to-lymphocyte ratio, platelet-to-lymphocyte ratio and platelet count as predictors of long-term outcome after R0 resection for colorectal cancer. Sci Rep. 2017; 7(1): 1494 .

12.Prodromidou A, Andreakos P, Kazakos C, Vlachos DE, Perrea D, Pergialiotis V. The diagnostic efficacy of platelet-to-lymphocyte ratio and neutrophil-to-lymphocyte ratio in ovarian cancer. Inflamm Res. 2017; 66(6):467-475. 
13.Turri-Zanoni M, Salzano G, Lambertoni A, Giovannardi M, Karligkiotis A, Battaglia P, et al. Prognostic value of pretreatment peripheral blood markers in paranasal sinus cancer: Neutrophil-tolymphocyte and platelet-to-lymphocyte ratio. Head Neck. 2017; 39(4):730-736.

14.Christakis NA, Lamont EB. Extent and determinants of error in doctors' prognoses in terminally ill patients: prospective cohort study. BMJ. 2000; 320(7233):469-472.

15.Barbot AC, Mussault P, Ingrand P, Tourani JM. Assessing 2-month clinical prognosis in hospitalized patients with advanced solid tumors. J Clin Oncol. 2008; 26(15):2538-2543.

16.Earle CC, Neville BA, Landrum MB, Ayanian JZ, Block SD, Weeks JC. Trends in the aggressiveness of cancer care near the end of life. J Clin Oncol. 2004; 22(2):315-321.

17.Gripp S, Moeller S, Bolke E, Schmitt G, Matuschek C, Asgari S, et al. Survival prediction in terminally ill cancer patients by clinical estimates, laboratory tests, and self-rated anxiety and depression. J Clin Oncol. 2007; 25(22):3313-3320.

18.Amano K, Maeda I, Shimoyama S, Shinjo T, Shirayama H, Yamada T, et al. The Accuracy of Physicians' Clinical Predictions of Survival in Patients With Advanced Cancer. J Pain Symptom Manage. 2015: 50(2):139-146 e131.

19.Deng M, Ma X, Liang X, Zhu C, Wang M. Are pretreatment neutrophil-lymphocyte ratio and platelet-lymphocyte ratio useful in predicting the outcomes of patients with small-cell lung cancer? Oncotarget. 2017; 8(23):37200-37207.

20.Kasmann L, Bolm L, Schild SE, Janssen S, Rades D. Neutrophil-toLymphocyte Ratio Predicts Outcome in Limited Disease Small-cell Lung Cancer. Lung. 2017; 195(2):217-224.

21.Kang MH, Go SI, Song HN, Lee A, Kim SH, Kang JH, et al. The prognostic impact of the neutrophil-to-lymphocyte ratio in patients with small-cell lung cancer. Br J Cancer. 2014; 111(3):452-460.

22.Caliskan S, Sungur M, Kaba S, Ozsoy E, Koca O, Ozturk MI. Neutrophil-to-Lymphocyte Ratio in Renal Cell Carcinoma Patients. Folia Med (Plovdiv). 2018; 60(4):553-557.

23.Zhan H, Ma JY, Jian QC. Prognostic significance of pretreatment neutrophil-to-lymphocyte ratio in melanoma patients: A meta-analysis. Clin Chim Acta. 2018; 484:136-140.

24.Szor DJ, Dias AR, Pereira MA, Ramos M, Zilberstein B, Cecconello I, et al. Prognostic Role of Neutrophil/Lymphocyte Ratio in Resected Gastric Cancer: A Systematic Review and Meta-analysis. Clinics (Sao Paulo). 2018; 73:e360.

25.Zhou Y, Wei Q, Fan J, Cheng S, Ding W, Hua Z. Prognostic role of the neutrophil-to-lymphocyte ratio in pancreatic cancer: A metaanalysis containing 8252 patients. Clin Chim Acta. 2018; 479:181-189. 26.Ethier JL, Desautels D, Templeton A, Shah PS, Amir E. Prognostic role of neutrophil-to-lymphocyte ratio in breast cancer: a systematic review and meta-analysis. Breast Cancer Res. 2017; 19(1):2.

27.Bowen RC, Little NAB, Harmer JR, Ma J, Mirabelli LG, Roller $\mathrm{KD}$, et al. Neutrophil-to-lymphocyte ratio as prognostic indicator in gastrointestinal cancers: a systematic review and meta-analysis. Oncotarget. 2017; 8(19):32171-32189.

28.Kiriu T, Yamamoto M, Nagano T, Hazama D, Sekiya R, Katsurada $\mathrm{M}$, et al. The time-series behavior of neutrophil-to-lymphocyte ratio is useful as a predictive marker in non-small cell lung cancer. PLoS One. 2018; 13(2):e0193018.

29.Lau F, Downing GM, Lesperance M, Shaw J, Kuziemsky C. Use of Palliative Performance Scale in end-of-life prognostication. J Palliat Med. 2006; 9(5):1066-1075.

30.Chow E, Abdolell M, Panzarella T, Harris K, Bezjak A, Warde P, et al. Predictive model for survival in patients with advanced cancer. $J$ Clin Oncol. 2008; 26(36):5863-5869.

31.Tredan O, Ray-Coquard I, Chvetzoff G, Rebattu P, Bajard A, Chabaud S,et al. Validation of prognostic scores for survival in cancer patients beyond first-line therapy. BMC Cancer. 2011; 11:95. 